\title{
Analysis of the corneal endothelium in eyes of chickens using contact specular microscopy
}

\author{
Análise do endotélio da cornea de galinhas utilizando à microscopia \\ especular de contato
}

\author{
Luciane de Albuquerque ${ }^{1 *}$; Luciana Vicente da Rosa Pacicco Freitas²; \\ João Antonio Tadeu Pigatto ${ }^{3}$
}

\begin{abstract}
The corneal endothelium is a single layer of polygonal cells essential for corneal transparency. The objective of this study was to assess the parameters corneal endothelial cells in healthy chickens of different ages using a contact specular microscopy. A total 36 eyes of 18 chickens were evaluated in this study. After the humane slaughter of birds and subconjunctival enucleation, the eye bulbs were arranged into three groups according to the age of the chickens. Group 1 consisted of bulbs eyes of 6 chickens with ages ranging from 1 to 3 months old. Group 2 consisted of ocular bulbs 6 chickens with ages ranging from 5 to 12 months old. Group 3 consisted of bulbs eyes of 6 chickens with ages ranging from 24 to 40 months old. The contact specular microscopy was easy to perform and provided data such as endothelial cell density, average cell area and cellular pleomorphism. The results obtained with a contact specular microscopy revealed that the aging causes a decrease in the density of the corneal endothelium healthy chickens. Similarly, increasing the average endothelial cell area as well as the pleomorphism occurs. The present work suggests that the parameters of corneal endothelium of healthy chickens present change with advancing age.
\end{abstract}

Key words: Chickens, cornea, endothelium, contact specular microscopy

\section{Resumo}

Objetivou-se avaliar os parâmetros do endotélio da córnea de galinhas saudáveis de diferentes faixas etárias utilizando a microscopia especular de contato. Foram avaliados 36 bulbos oculares de 18 galinhas. Após o abate humanitário das aves e a enucleação subconjuntival, os bulbos oculares foram dispostos em três grupos distintos de acordo com a faixa etária. O grupo 1 foi composto por bulbos dos olhos de 6 galinhas com idades variando entre 1 a 3 meses de idade. $O$ grupo 2 foi formado por bulbos oculares de 6 galinhas com idades variando entre 5 a 12 meses de idade. Já o grupo 3 consistiu em bulbos oculares de 6 galinhas com idades variando entre 24 a 40 meses de idade. A microscopia especular de contato foi de fácil realização e forneceu dados como a densidade de células endoteliais, área celular média e o pleomorfismo celular. Os resultados obtidos com esse exame revelaram que o avanço da idade acarreta na diminuição da densidade do endotélio da córnea de galinhas. Além disso, ocorre o aumento da área celular endotelial média bem como do pleomorfismo. O presente trabalho sugere que os parâmetros do endotélio da córnea de galinhas apresentam mudanças com o avanço da idade.

Palavras-chave: Galinhas, córnea, endotélio, microscopia especular de contato

\footnotetext{
${ }^{1}$ Médica Veterinária, Discente, Universidade Federal do Rio Grande do Sul, UFRGS, Porto Alegre, RS, Brasil. E-mail: lucialbuquerque@hotmail.com.br

${ }^{2}$ Prof', UFRGS, Porto Alegre, RS, Brasil. E-mail: pigatto@ufrgs.br

${ }^{3}$ Médica Veterinária, Discente, UFRGS, Porto Alegre, RS, Brasil. E-mail: lvpf@hotmail.com.br

* Author for correspondence
} 


\section{Introduction}

The corneal endothelium is a single layer of polygonal cells covering the corneal posterior surface (TUFT; COSTER, 1990). The endothelial integrity and metabolic activity are essential for continuous maintenance of corneal dehydration and transparency (WARING et al., 1982). Ageing results in a gradual reduction in endothelial cell density and an increase in cell area variability in those species that exhibit minimal mitotic potential. Furthermore, morphological changes of endothelium associated with cell loss occur in many conditions including corneal dystrophies, keratoconus, glaucoma, uveitis, blunt ocular trauma, cataract extraction, and penetrating keratoplasty (TUFT; COSTER, 1990).

The specular microscopy has become a standard technique to determine endothelial cell counting and cell morphology (LAING et al., 1976). Used in preoperative evaluation for cataract surgery in humans and animals (RENZO et al., 2014). Among the useful parameters to determine endothelial cell status are the endothelial cell density and cell morphology (SABATER etal., 2013). Pleomorphism is the variation of cell shape such as percentage of hexagonal cells (LAING et al., 1976).

Despite the relative widespread availability of instruments to the assessment of the endothelial mosaic, there are few reports on endothelial morphology of vertebrates, particularly chickens. Studies found on the corneal endothelium in birds used scanning electron microcopy (COLLIN; COLLIN, 1998; PIGATTO et al., 2005a, 2009). Furthermore, in the ophthalmology chickens have been employed for experimental studies. Moreover, the knowledge about the corneal endothelium of animals has great interest for research purposes, since it can be applied to study corneal diseases, glaucoma, intraocular drugs and intraocular surgical procedures. Moreover, pre-clinical studies using experimental animal models are necessary for corneal endothelial research oriented towards clinical applications in order to confirm the long- term effect and safety of treatments and procedures. The objective of this study was to assess the corneal endothelial cells in normal eyes of chickens using specular microscopy.

\section{Material and Methods}

All experiments were carried out in accordance with the ARVO Statement for the Use of Animals in Ophthalmic and Visual Research. Sixty normal eyes from thirty White Leghorn chickens (Gallus gallus domesticus), obtained from a licensed Brazilian commercial company (Avisui abbattoir) that breeds these animals for meat production were used. The chickens were supplied with food and water ad libitum.

Each group consisted of six chickens. Group 1 consisted of chickens with ages ranging from 1 to 3 months old. Group 2 consisted of chickens with ages ranging from 5 to 12 months old. Group 3 consisted of chickens with ages ranging from 24 to 40 months old. Ophthalmic examination was performed before beginning the study on each subject. The examination consisted of slitlamp biomicroscopy (Portable Slit Lamp Kowa SL15, Japan by rebound tonometry with setting p (Tonovet; Tiolat, Helsinki, Finland), indirect ophthalmoscopy with a 30D condensing lens ( Binocular indirect ophthalmoscope, Eyetec OHN 3.5 FC, São Carlos, Brazil) and by fluorescein staining (Sodium fluorescein at 1\%; Ophthalmos, Sao Paulo, Brazil). Eyes that showed evidence of ocular disease were excluded. For the practice of euthanasia, the birds were anesthetized with isoflurane using induction box and of gaze soaked with and after anesthetic was used $75 \mathrm{mg}$ of sodium thiopental intraperitoneal. Eyes were enucleated immediately after chickens were sacrificed and stored in moist chamber. Studies of these corneas were initiated within $1 \mathrm{~h}$ after enucleation. Eyes were mounted on an eyeball holder and examined using a contact specular microscope (Celmax Medical Service, Brazil), with software for corneal 
endothelium analysis. Specular microscopy was performed on all eyes in orders to determine the conditions of the corneal endothelium and those with evidence of alteration were excluded. All analyses were carried out by the same investigator (JATP). Three micrographs of the corneal endothelium were taken from the central region of each cornea. Endothelial cell density, average cell area and pleomorphism were obtained from both eyes. The corneal endothelial cell analysis was done with a fixed frame analysis method. Statistical data analysis was conducted using the Tukey test. Values of $\mathrm{P}<0.01$ were considered significant.

\section{Results}

Images were obtained for all eyes. The specular microscopy showed that normal chickens corneal endothelium was characterized by a continuous monolayer of polygonal cells of uniform size and shape (Figure 1). Reproducible images were obtained from all eyes.

Figure 1. Image specular microscopy showing that normal chickens corneal endothelium.

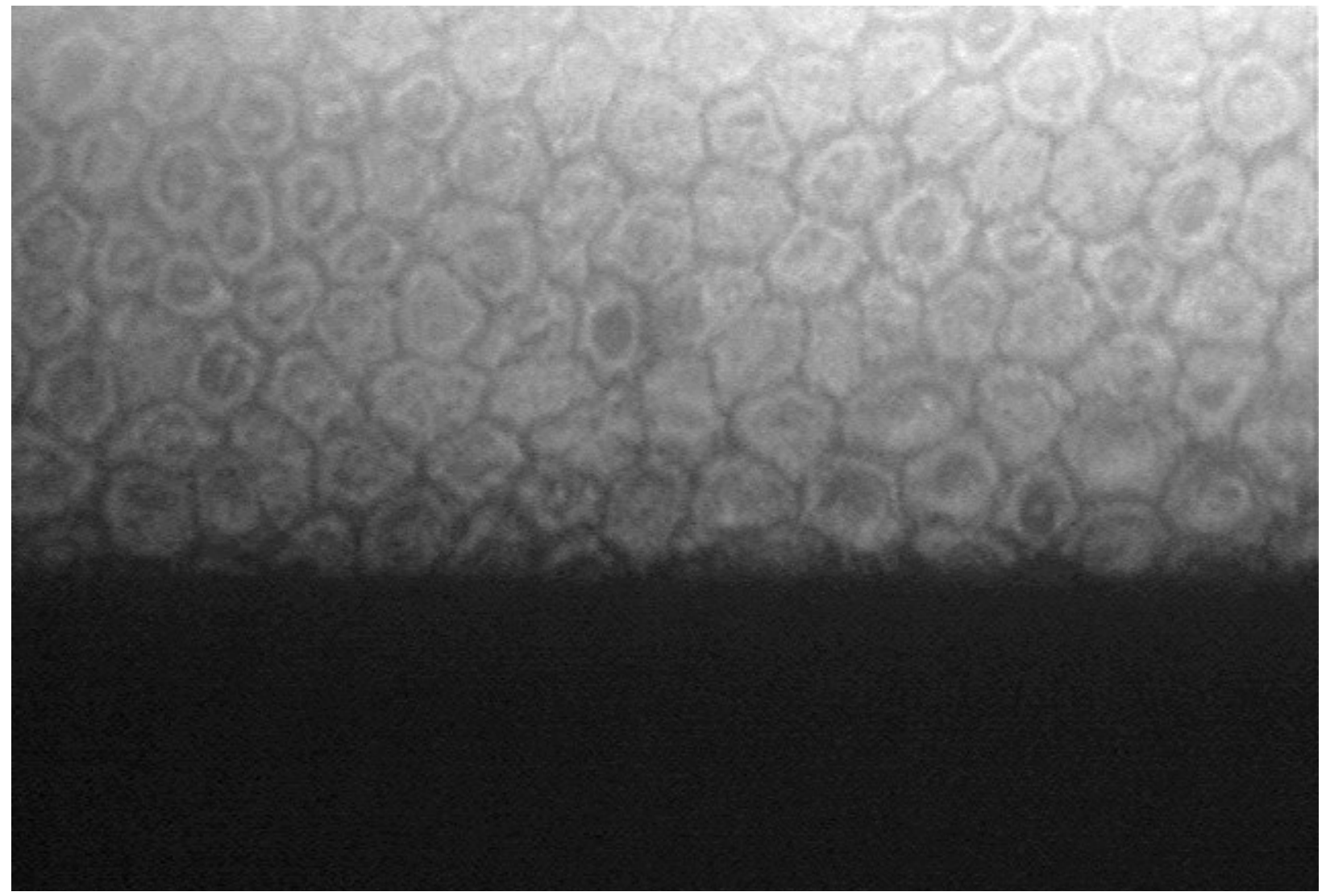

The mean ECD was $6.424 \pm 572$ cells $\mathrm{mm}^{-2}$. The mean ECD for Group 1 was $8.526 \pm 371$ cells mm$^{-2}$. The mean ECD for Group 2 was $6.124 \pm 771$ cells $\mathrm{mm}^{-2}$. The mean ECD for Group 3 was $4.623 \pm 702$ cells $\mathrm{mm}^{-2}$. Cell density decreased with age. The results showed that there was significant difference between the three groups $(P<0.001)$.

The average cell area of corneal endothelium was $166.51 \mu \mathrm{m}^{2}$. Endothelial area in the chickens of Group 1 ranged between $111.78 \mu \mathrm{m}^{2}$ and 126.66 $\mu \mathrm{m}^{2}$ with mean of $118.11 \mu \mathrm{m}^{2}$. Endothelial area in the chicken of Group 2 ranged between 151.19 
$\mu \mathrm{m}^{2}$ and $180.77 \mu \mathrm{m}^{2}$ with mean of $164.18 \mu \mathrm{m}^{2}$. Endothelial area in the chickens of Group 3 ranged between $199.11 \mu \mathrm{m}^{2}$ and $232.38 \mu \mathrm{m}^{2}$ with mean of $217.24 \mu \mathrm{m}^{2}$. There were significant difference between three groups $(P<0.001)$.

In regard to morphology, the majority of endothelial cells were six-sided (64\%). In group $1.69 \%$ of the cells had six-sided, $29 \%$ had five-sided, $1 \%$ had four-sided, $1 \%$ had seven-sided. In group $2.64 \%$ of the cells had six-sided, $32 \%$ had fivesided, $2 \%$ had four-sided, and $2 \%$ had seven-sided. In group $3.60 \%$ of cells showed six-sided, $36 \%$ had five-sided, three-sided made $3 \%$ and $1 \%$ had sevensided. The results showed that there was significant difference between the three groups $(P<0.001)$.

Pleomorphism in the chickens of Group 1 ranged between $64 \%$ and $80 \%$ with mean of $74.5 \%$. Pleomorphism in the chickens of Group 2 ranged between $64 \%$ and $78 \%$ with mean of $71.5 \%$. Pleomorphism in the chickens of Group 3 ranged between $66 \%$ and $79 \%$ with mean of $73.9 \%$. The results showed that there no was significant difference between the three groups $(P=0.329)$.

There were no significant difference between the right and left eyes for all evaluated parameters $(P$ $=0.119$ ).

\section{Discussion}

The endothelial integrity and metabolic activity are essential for continuous maintenance of corneal dehydration and transparency (SABATER et al., 2013; WARING et al., 1982). A decrease below a critical threshold results in corneal edema and subsequent vision loss (SABATER et al., 2013).

Despite the relative widespread availability of instruments for in vivo or in vitro assessment of the endothelial mosaic, there are few detailed reports on endothelium of other vertebrates, particularly chickens (PIGATTO et al., 2005a, 2009; YEE et al., 1987). The choice of chickens was due to the wide applicability of this species in ophthalmic research
(KAFARNIK et al., 2007; NICKLA et al., 1998; PRASHAR et al., 2007; SCHMID et al., 2003; TSUKAHARA et al., 2010; WAGGONER, 1978). The chicken has been used extensively as a myopia model (WAGGONER, 1978). Furthermore, in the future maybe the chickens can be included as an experimental model for evaluating drugs, storage solutions for transplants or surgical procedures with effects on the corneal endothelium (RITCHEY et al., 2011; WAHL et al., 2010). Chickens are relatively small and do not require large spaces which make it easy to control and monitor experiments on a daily basis. At last, chickens are relatively inexpensive and easy to obtain compared with other animals.

Specular microscopy and scanning electron microscopy have been used to evaluate the corneal endothelium of other vertebrates. Changes in endothelial cell dimensions can occur as a result of processing cornea for scanning electron microscopy (SCHUTTEN; VAN HORN, 1980). In spite of this limitation, the scanning electron microscopy has been widely used to compare the endothelial ultrastructure of vertebrates, and to evaluate the effects of medications, chemicals or surgical procedures on the endothelium (COLLIN; COLLIN, 1998; PIGATTO et al., 2004, 2005a). Specular microscopy has become a standard technique to determine endothelial cell density and cell morphology in vivo. The specular microscope has been used to quantify endothelial cell size in humans, dogs, rabbits, horses and other animal species (ABIB; BARRETO, 2001; ANDREW et al., 2001; GWIN et al., 1982; MORITA, 1995; PEIFFER et al., 1981; PIGATTO et al., 2006; RENZO, 2014; STAPLETON; PEIFFER, 1979; SZALAI, 2011). However, most studies do not report the evaluation of the parameters endothelial cells and their relation with aging in birds. In the present study, animals of different ages were selected to evaluate the relationship between age and the animal endothelial morphology.

Enucleated eyes were used in this study. The utilization of eyes within $1 \mathrm{~h}$ after enucleation 
allowed the maintenance of endothelial ultrastructure. Previous studies have shown that the data obtained within six hours after death may be regarded as those obtained from live animals (ANDREW et al., 2001; FRANZEN et al., 2010; PIGATTO et al., 2006; RODRIGUES et al., 2006; VICENTI, 2004).

Specular microscopy demonstrated that the endothelium was continuous and without detectable abnormalities in all eyes examined. Results of the present study, using specular microscopy to determine ECD, present an avarange of 6.424 cells $\mathrm{mm}^{-2}$. Other studies have also evaluated the endothelial behavior in different age groups. Peiffer et al. (1981), studying corneal endothelial cell of clinical normal feline with 1 and 3 years of age, found an average number of 2.668 cells $\mathrm{mm}^{-}$ ${ }^{2}$. Franzen et al. (2010) also evaluated the behavior of endothelial cats in three age groups using microscopy speculate and obtained an average was 4.482 cells $\mathrm{mm}^{-2}$. As well as those studies, endothelial cell density decreases in corneas of normal chickens with age. These data are consistent with other published studies. Gwin et al. (1982) and Morita (1995) reported a decrease in endothelial cell density with advancing age in dogs and rabbits, respectively. Endothelial cell density decreases with advancing age in humans and other animals (ABIB; BARRETO, 2001; ANDREW et al., 2002; FRANZEN et al., 2010; GWIN et al., 1982; LAING et al., 1976; YEE et al., 1987). As well as observed in this study, in most species the endothelium low regenerative ability is compensated by the growing in size of endothelial cells while endothelial cell density declines (MORITA, 1995; MISHIMA, 1981; SZALAI et al., 2011; WARING et al., 1982). The endothelium is a monolayer of polygonal cells which maintains corneal transparency by keeping the stroma in a state of relative dehydration (WARING et al., 1982). The results observed in this study show that normal chickens corneal endothelium was characterized by a monolayer of polygonal cells of uniform size and shape. As similarly reported in previous studies on corneal endothelium of birds, the predominant number of cells in the chickens corneal endothelium were hexagonal in shape, with pentagonal and heptagonal cells constituting the remaining endothelium. In most vertebrates the shape of normal corneal endothelial cells is typically a mixture of hexagonal and pentagonal cells (ABIB; BARRETO, 2001; ANDREW et al., 2002; FRANZEN et al., 2010; GWIN et al., 1982; MISHIMA, 1981; PIGATTO et al., 2004, 2005a, 2005b, 2009; RODRIGUES et al., 2006). This pattern of distribution for polygonality is in accordance with studies conducted in humans, rabbits and other vertebrates, where 59$80 \%$ of corneal endothelial cells were hexagonal (FRANZEN et al., 2010; PADILLA et al., 2004; PIGATTO et al., 2005a, 2005b, 2009).

In the present study, we have not analyzed the relation between gender and endothelial parameters. Previous studies in humans, dogs, pigs and rabbits observed that the corneal endothelium is not influenced by gender, relative to the parameters analyzed endothelial (GWIN et al., 1982; MORITA, 1995; TAMAYO-ARANGO et al., 2009). Further studies are expected in order to confirm if gender may influence on these parameters within chickens.

\section{Conclusion}

The present work suggests that the parameters of corneal endothelium of healthy chickens present change with advancing age. Furthermore the density of the corneal endothelial cells declines with increasing age in chickens, with gradual increases in pleomorphism.

\section{Acknowledgements}

This study would not be possible without the cooperative AVISUI food industry (Santa Maria, RS, Brazil) that kindly cooperated by giving us the eyes globes and the space to develop the research. 


\section{References}

ABIB, F. C.; BARRETO, J. Behavior of corneal endothelial density over a lifetime. Journal of Cataract and Refractive Surgery, Fairfax, v. 27, n. 10, p. 15741578, 2001.

ANDREW, S. E.; RAMSEY, D. T.; HAUPTAMN, J. G.; BROOKS, D. E. Density of corneal endothelial cells and corneal thickness in eyes of euthanatized horses. American Journal of Veterinary Research, Washington, v. 62 , n. 4, p. 479-482, 2001.

ANDREW, S. E.; WILLIS, A. M.; ANDERSON, D. E. Density of corneal endothelial cells, corneal thickness, and corneal diameters in normal eyes of llama and alpacas, American Journal of Veterinary Research, Washington, v. 63, n. 3, p. 326-329, 2002.

COLLIN, S. P.; COLLIN, H. B. Comparative study of the corneal endothelium in vertebrates. Clinical and Experimental Optometry, Sydney, v. 81, n. 6, p. 245-254, 1998.

FRANZEN, A. A.; PIGATTO, J. A.; ABIB, F. C.; ALBUQUERQUE, L.; LAUS, J. L. Use of specular microscopy to determine corneal endothelial cell morphology and morphometry in enucleated cat eyes. Veterinary Ophthalmology Journal, Idaho, v. 13, n. 4, p. 222-226, 2010.

GWIN, R. M.; LERNER, I.; WARREN, J. K.; GUM, G. L. Decrease in canine corneal endothelial cell density and increase in corneal thickness as function of age. Investigative Ophthalmology and Visual Science, Rockville, v. 22, n. 5, p. 267-271, 1982.

KAFARNIK, C.; FRITSCHE, J.; REESE, S. In vivo confocal microscopy in the normal corneas of cats, dogs and birds. Veterinary Ophthalmology, Idaho, v.10, n.4, p. 222-230, 2007.

LAING, R. A.; SANDSTROM, M. M.; BERROSPI, A. P.; LEIBOWITZ, H. Changes in the corneal endothelium as a function of age. Experimental Eye Research, Amsterdam, v. 22, n. 6, p. 587-594, 1976.

MISHIMA, S. Clinical investigations on the corneal endothelium. American Journal of Ophthalmology, Jacksonville, v. 93, n. 1, p. 1-29, 1981.

MORITA, H. Specular microscopy of corneal endothelial cells in rabbits. The Journal of Veterinary Medical Science, Tokio, v. 57, n. 2, p. 273-277, 1995.

NICKLA, D. L.; WILDSOET, C.; WALLMAN, J. The circadian rhythm in intraocular pressure and its relation to diurnal ocular growth changes in chicks. Experimental Eye Research, Amsterdam, v. 66, n. 2, p. 183-193, 1998.
PADILLA, M. D. B.; SIBAYAN, S. A. B.; GONZALES, C. S. A. Corneal endothelial cell density and morphology in normal Filipino eyes. Cornea, Philadelphia, v. 23, n. 2, p. 129-135, 2004.

PEIFFER, R. L.; DEVANZO, R. J.; COHEN, K. L. Specular microscopic observations of clinically normal feline corneal endothelium. American Journal of Veterinary Research, Jacksonville, v. 42, n. 5, p. 854-855, 1981.

PIGATTO, J. A. T.; CERVA, C.; FREIRE, C. D.; ABIBI, F. C.; BELLINI, L. P.; BARROS, P. S. M.; LAUS, J. L. Morphological analysis of the corneal endothelium in eyes of dogs using specular microscopy. Pesquisa Veterinária Brasileira, Rio de Janeiro, v. 28, n. 9, p. 427430, 2008.

PIGATTO, J. A. T.; ABIB, F. C.; PEREIRA, G. T.; BARROS, P. S. M.; FREIRE, C. D.; LAUS, J. L. Density of corneal endothelial cells in eyes of dogs using specular microscopy. Brazilian. Journal of Veterinary Research and Animal. Science, São Paulo, v. 43, n. 4, p. 476-480, 2006.

PIGATTO, J. A. T.; ABIB, F. C.; PIZZETI, J. C.; LAUS, J. L.; SANTOS, J. M.; BARROS, P. S. M. BARROS. Morphometric analysis of the corneal endothelium of rabbits using scanning electron microscopy. Acta Scientiae. Veterinary, Porto Alegre, v. 39, n. 3, p. 41-45, 2005b.

PIGATTO, J. A. T.; ANDRADE, M. C.; LAUS, J. L.; SANTOS, J. M.; BROOKS, D. E.; GUEDES, P. M.; BARROS, P. S. M. Morphometric analysis of the corneal endothelium of Yacare caiman (Caiman yacare) using scanning electron microscopy. Veterinary Ophthalmology Journal, Idaho, v. 7, n. 3, p. 205-208, 2004.

PIGATTO, J. A. T.; FRANZEN, A. A.; PEREIRA, F. Q.; ALMEIDA, A. C. V. R.; LAUS, J. L.; SANTOS, J. M.; GUEDES, P. M.; BARROS, P. S. M. Scanning electron microscopy of the corneal endothelium of ostrich. Ciência Rural, Santa Maria, v. 39, n. 4. p. 926-929, 2009.

PIGATTO, J. A. T.; LAUS, J. L.; SANTOS, J. M.; CERVA, C.; CUNHA L. S.; RUOPPOLO, V.; BARROS, P. S. M. Corneal endothelium of the Magellanic penguin (Spheniscus magellanicus) by scanning electron microscopy. Journal Zoo and Wildlife Medicine, Yulee, v. 36, n. 4, p. $702-705,2005$ a.

PRASHAR, A.; GUGGENHEIM, J. A.; ERICHSEN, J. T.; HOCKING, P. M.; MORGAN, J. E. Measurement of intraocular pressure (IOP) in chickens using a rebound tonometer: qualitative evaluation of variance due to position inaccuracies. Experimental Eye Research, Amsterdam, v. 85, p. 563-571, 2007. 
RENZO, R.; RIBEIRO, A. P.; SILVA, M. L.; SILVA, G. A.; ORTENCIO, K. P.; BARROS SOBRINHO, A. A.; MINEO, T. W.; LAUS, J. L. Intraocular pressure, specular microscopy, and prostaglandin E2 concentration in dogs with mature and hypermature cataract. Veterinary Ophthalmology, Idaho, v. 4, n. 17, p. 280-285, 2014.

RITCHEY, E. R.; CODE, K.; ZELINKA, C. P.; SCOTT, M. A.; FISCHER, A. J. The chicken cornea as a model of wound healing and neuronal re-innervation. Molecular Vision, Georgia, v. 17, n. 1, p. 2440-2454, 2011.

RODRIGUES, G. N.; LAUS, J. L.; SANTOS, J. M.; RIGUEIRO, M. P.; SMITH, R. L. Corneal endothelial cell morphology of normal dogs in different ages. Veterinary Ophthalmology, Idaho, v. 9, n. 2, p. 101-107, 2006.

SABATER, A. L.; GUARNIERI, A.; ESPANA, E. M.; LI, W.; PROSPER, F.; MORENO-MONTANES, J. Strategies of human corneal endotelial tissue regeneration. Journal of Regenerative Medicine, Texas, v. 8, n. 2, p. 183-195, 2013.

SCHMID, K. L.; HILL, T.; ABBOTT, M.; HUMPHRIES, M.; PYNE, K.; WILDSOET, C. F. Relationship between intraocular pressure and eye growth in chick. Ophthalmology Physiology and Optics, Hoboken, v.23, n.2, p.25-33, 2003.

SCHUTTEN, W. H.; VAN HORN, D. L. Corneal endothelial cell shrinkage after critical point drying. Annals of Ophthalmology, Norristown, v. 12, n. 2, p. 1165-1167, 1980.

STAPLETON, S.; PEIFFER, R. Specular microscopic observations of the clinically normal canine corneal endothelium. American Journal of Veterinary Research, Washington, v. 40, n. 12, p. 1803-1804, 1979.

SZALAI, E.; NEMETH, G.; BERTA, A.; MODIS, L. Evaluation of the corneal endothelium using noncontact and contact specular microscopy. Cornea, Philadelphia, v. 30, n. 5 , p. $567-571,2011$.
TAMAYO-ARANGO, L.; BARALDI-ARTONI, S. M.; LAUS, J. L.; VICENTI, F. A. M.; PIGATTO, J. A. T.; ABIB, F. C. Ultrastructural morphology and morphometry of the normal corneal endothelium of adult crossbred pig. Ciência Rural, Santa Maria, v. 39, n. 1, p. 117-122, 2009.

TSUKAHARA, N.; TANI, Y.; LEE, E.; KIKUCHI, H.; ENDOH, K.; ICHIKAWA, M.; SUGITA, S. Microstructure characteristics of the cornea in birds and mammals. The Journal of Veterinary Medical Science, Tokio, v. 72, n. 9, p. 1137L1143, 2010.

TUFT, S. J.; COSTER, D. J. The corneal endothelium. Eye, London, v. 4, n. 2, p. 389-424, 1990.

VICENTI, F. M. Morfologia e morfometria do endotélio corneano de suínos (Sus scrofa domesticus, LINNAEUS, 1758) à microscopia especular. 2004. Tese (Doutorado), Universidade Estadual Paulista, Faculdade de Ciências Agrárias e Veterinárias, Jaboticabal.

WAGGONER, P. R. Scanning electron microscopy of the developing chick anterior corneal epithelium. Journal of Embryology and Experimental Morphology, Cambridge, v. 44 , p. 217-225, 1978.

WAHL, C.; LI, T.; TAKAGI, Y.; HOWLAND, H. The effects of light regimes and hormones on corneal growth in vivo and in organ culture. Journal of Anatomy, Texas, v. 219, n. 6, p. 766-775, 2011.

WARING, G. O.; BOURNE, W. M.; EDELHAUSER, H. F. The corneal endothelium: normal and pathologic structure and function. Ophthalmology, Rochester, v. 89, n. 6, p. 531-590, 1982 .

YEE, R. W.; EDELHAUSER, H. F.; STERN, M. E. Specular microscopy of vertebrae corneal endothelium: a comparative study. Experimental Eye Research, Amsterdam, v. 5, n. 44, p. 703-714, 1987. 
